\title{
The prevalence and risk factors for dyslipidaemia in human immunodefi- ciency virus-infected children on highly active antiretroviral therapy in Kano, Nigeria
}

\author{
Oiza Ozioroko Aliu-Isah, ${ }^{1}$ Fatima Hassan-Hanga,${ }^{1}$ Isah Adagiri Yahaya, ${ }^{2}$ Oyeku Akibu \\ Oyelami, ${ }^{3}$ Henry Abiodun Aikhionbare ${ }^{4}$
}

${ }^{1}$ Department of Paediatrics, ${ }^{2}$ Department of Chemical Pathology, Faculty of Clinical Sciences, College of Health Sciences, Bayero University, Aminu Kano Teaching Hospital, Kano; ${ }^{3}$ Department of Paediatrics and Child Health, Obafemi Awolowo University Teaching Hospital, Ile-Ife; ${ }^{4}$ Department of Child Health, University of Benin Teaching Hospital, Benin City, Nigeria

\begin{abstract}
Prolonged administration of Highly Active Anti Retroviral Therapy (HAART) is associated with metabolic side effects, especially dyslipidaemia, with potential increase in the risk of develop-
\end{abstract}

Correspondence: Dr. Aliu-Isah OO, Department of Paediatrics, Faculty of Clinical Sciences, College of Health Sciences, Bayero University,/Aminu Kano Teaching Hospital, Kano.

Tel.: +2348037051457

E-mail: oizaai2@yahoo.com

Key words: Human immunodeficiency virus, highly active antiretroviral therapy (HAART), HAART-naive, Dyslipidaemia.

Contributions: AIOO, conceptualized and designed the study, acquired, analyzed and interpreted the data, drafted the article, revised it critically for important intellectual content, and approved the final submitted version; HHF designed the study, and acquired, analyzed and interpreted the data, drafted the article, revised it critically for important intellectual content, and approved the final submitted version; YIA designed the study, and acquired, analyzed and interpreted the data, drafted the article, revised it critically for important intellectual content, and approved the final submitted version; OOA and AHA analyzed and interpreted the data, drafted the article and revised it critically for important intellectual content, and approved the final submitted version.

Conflict of interest: The authors declare no conflict of interest

Funding: Self-funded.

Ethics approval and consent to participate: Ethical clearance for the study was obtained from the Research and Ethical Committee of the Hospital. Informed consent was also obtained from the parent(s) or care-giver(s) and assent was obtained for children older than eight years of age.

Received for publication: 5 February 2020.

Accepted for publication: 20 July 2020.

This work is licensed under a Creative Commons Attribution NonCommercial 4.0 License (CC BY-NC 4.0).

CC Copyright: the Author(s),2020

Licensee PAGEPress, Italy

Annals of African Medical Research 2020; 3:103

doi:10.4081/aamr.2020.103 ment of cardiovascular disease as the affected children mature into adulthood. This study determined the prevalence and risk factors for dyslipidaemia among HIV infected children aged 2-15 years. The study was a comparative study conducted on children aged 215 years attending the Paediatric Infectious Disease Clinic of the Aminu Kano Teaching Hospital, Kano. Study subjects that fulfilled the inclusion criteria were recrutited using systematic sampling technique. Serum lipid profile parameters were measured on blood samples from eighty HIV-infected children on HAART and eighty HIV-infected HAART naive children as patients and controls respectively. Data was analysed using the SPSS software for Windows version 16.0. P-values of $<0.05$ were considered as statistically significant. The overall prevalence of dyslipidaemia in HIVinfected children on HAART was $62.5 \%$ (95\% CI: $51.8 \%$ $73.1 \%$ ), while $52.5 \%$ (95\% CI: $41.5 \%-63.4 \%)$ of the HIV- infected HAART naive children also had dyslipidaemia. The risk factors associated with hypercholesterolaemia were: age at commencement of HAART less than 2 years $(\mathrm{P}<0.048$; Adjusted Odds Ratio,OR, of 0.38, 95\% CI:0.13-1.08) and PI- based HAART regimen $(\mathrm{P}<0.001 ; \mathrm{OR}=0.18$, 95\% CI: 0.07-0.49), while age group greater than 5 years $(\mathrm{P}<0.02$; OR $=2.78$ (95\% CI:0.76-10.23), duration of HIV diagnosis greater than one year $(\mathrm{P}<0.02$ fisher's exact) and duration of treatment on HAART for more than one year ( $\mathrm{P}<0.04$; OR $=2.32,95 \% \mathrm{CI}: 0.14-38.99)$ were the risk factors associated with hypertriglyceridaemia among the HIV infected children on HAART. However, on multivariate analysis, PI-based HAART regimen was the only independent predictor of hypercholesterolaemia in the HAART treated children $(\mathrm{OR}=0.18,95 \% \mathrm{CI}$ : 0.07-0.49). Duration of diagnosis greater than 1 year was associated with hypercholesterolaemia in HAART naïve HIV-infected children $(\mathrm{P}=0.05)$.

The most common dyslipidaemia in HIV-infected children on HAART was hypertriglyceridaemia followed by hypercholesterolaemia while low HDL-cholesterol was the commonest lipid abnormality in the HIV-infected HAART naive children.

\section{Introduction}

HIV infection has become a chronic disease in paediatric patients as access to Antiretroviral Therapy (ART) has significantly improved the prognosis and potential for long-term survival. ${ }^{1}$ Highly Active Antiretroviral Therapy (HAART) which consists of Protease Inhibitors (PIs) or Non-Nucleoside Reverse Transcriptase Inhibitors (NNRTIs) in combination with Nucleoside Reverse Transcriptase Inhibitors (NRTIs) has led to dramatic improvements in the management of HIV-infected patients. ${ }^{2}$ Although these anti- 
retroviral therapies are usually well tolerated, previously unrecognized side effects are becoming more evident with their widespread usage. ${ }^{2,3}$ Frequently encountered metabolic side effects include dyslipidaemia, altered glucose metabolism, insulin resistance, elevated free fatty acids, fat redistribution syndrome or lipodystrophy, lactic acidosis and bone density abnormalities. ${ }^{4}$ These metabolic complications of ART have been well documented in adults, but paediatric cohort studies are limited. ${ }^{5}$ The NRTIs are closely linked to lipodystrophy and lactic acidosis, while the PIs have consistently been associated with increased cholesterol and triglycerides in children which may potentially increase the risk of cardiovascular disease as they mature into adulthood. ${ }^{5}$

However, few studies have so far evaluated lipid profiles of children receiving HAART in sub-Saharan Africa, especially in Nigeria where over $90 \%$ of HIV-infected children reside. Most of the studies on lipid profiles of HIV-infected patients on HAART in Nigeria were done on the adult population.

As more children receive life-saving ARTs resulting in longer survival rates, understanding the adverse effects associated with exposure to ART is important for paediatricians and other health care workers who cater for these group of children and adolescents. It is thus imperative to determine these changes early so that timely intervention can be instituted to prevent complications and thus improve the quality of life of these children, ${ }^{6}$ hence the need for this study.

The aim of the study was to compare the prevalence and risk factors for dyslipidaemia among HIV-infected children on HAART and HIV-infected HAART naive children, aged 2-15 years, attending the Aminu Kano Teaching Hospital, Kano.

\section{Materials and Methods}

The study was carried out at the Paediatric Infectious Diseases Clinic (PIDC) of the Hospital on HIV infected children aged 2-15 years of age who were age- and sex- matched using systematic sampling technique. Eighty children receiving HAART for at least 3 months and 80 children not receiving ART were enrolled into the study from August, 2015 to March, 2016 as patients and controls respectively. HIV-infected children with confirmed renal disease, diabetes mellitus, cardiac disease or those on corticosteroids for at least one month prior to the commencement of the study were excluded from the study.

Ethical clearance for the study was obtained from the Research and Ethical Committee of the Hospital. Informed consent was also obtained from the parent(s) or care-giver(s) and assent was obtained for children older than eight years of age.

A proforma was used to collect information on each of the subjects at the time of recruitment. Socio-demographic data, including social class of the parents or caregivers, were recorded. The social class was classified using the Oyedeji socio-economic classification scheme. ${ }^{7}$

Under strict aseptic conditions, after cleaning the blood collection site thoroughly with $70 \%$ alcohol, five milliliters of non fasting venous blood was collected from each subject by venepuncture using lithium heparin vacutainer tubes. All samples were separated and then centrifuged at 3000 revolutions per minute for 10 minutes and the separated plasma stored at $-20 \square \mathrm{C}$ until analysis. The plasma samples were later analyzed for Total Cholesterol (TC), Low Density Lipoprotein Cholesterol (LDL-C), High Density Lipoprotein Cholesterol (HDL-C) and Triglycerides (TG) by enzymatic assay methods ${ }^{8,9}$ on Cobas Integra 400 series Chemistry autoanalyser. Low density lipoprotein cholesterol level was calcu- lated using the formula of Friedwald et al. ${ }^{10}$ Abnormal lipid levels, known as dyslipidaemia, were defined according to the National Cholesterol Education Programme (NCEP) guidelines. Subjects with values for $\mathrm{TC} \geq 200 \mathrm{mg} / \mathrm{dL}(5.2 \mathrm{mmol} / \mathrm{L}), \mathrm{LDL} \geq 130 \mathrm{mg} / \mathrm{dL}$ (3.4 $\mathrm{mmol} / \mathrm{L}), \mathrm{TG} \geq 150 \mathrm{mg} / \mathrm{dL}(1.69 \mathrm{mmol} / \mathrm{L})$ and $\mathrm{HDL} \leq 35 \mathrm{mg} / \mathrm{dL}$ $(0.91 \mathrm{mmol} / \mathrm{L})$ were considered to have dyslipidaemia.

Data obtained from the study were analyzed using the Statistical Package for Social Science (SPSS) software for Windows version 16.0 (University of Bristol). Data were presented in tables. Quantitative variables were summarized as mean \pm Standard Deviation (SD) or as median and inter-quatile range. Qualitative variables were described as frequencies and percentages. The Student " $t$ " test was used to compare mean values of variables, while proportion and percentages were compared using Chi-square $\left(\chi^{2}\right)$ test. Multivariate analysis was used to determine the effects of independent variables such as age, duration of diagnosis of HIV, duration on HAART, type of HAART and Dyslipidaemia on the final outcome (i.e., presence or absence of dyslipidaemia, which is the dependent variable). Level of statistical significance was set at $\mathrm{P} \leq 0.05$.

\section{Results}

Table 1 shows the baseline characteristics of the study subjects. Both patients and controls had the same composition of sexes with an overall male:female ratio of 1.4:1.

The study subjects were mostly of low socio-economic class belonging to social class IV.

The plasma concentrations of lipid profile parameters were higher in children receiving HAART compared to the HAART naive children and the differences were statistically significant for all the parameters except HDL-cholesterol (Table 2).

Fifty out of the eighty HIV-infected children on HAART had at least one abnormal lipid profile parameter, resulting in a prevalence of $62.5 \%$ (95\% CI: $51.8 \%$ - 73.1\%). While the prevalence of dyslipidaemia in HIV-infected HAART naive children was $52.5 \%$ (95\% CI: $41.5 \%-63.4 \%)$.

The most common dyslipidaemia in patients on HAART was hypertriglyceridaemia followed by hypercholesterolaemia, while low HDL-cholesterol was the commonest lipid abnormality in the HAART naive children (Table 3 ).

Commencement of HAART at age less than 2 years and PIbased HAART regimen were found to be significantly associated with hypercholesterolaemia in the patients on HAART (Table 4).

Duration of diagnosis greater than 1 year was associated with hypercholesterolaemia in HAART naïve HIV-infected children $(\mathrm{P}=0.05)$.

After controlling for possible confounders such as age and sex, only PI-based HAART regimen remained the predictor for hypercholesterolaemia among the HIV infected children on HAART $(\mathrm{P}=0.001 ; \mathrm{OR}=0.18,95 \% \mathrm{CI}: 0.07$ - 0.49) while non PI-based regimen was protective against hypercholesterolaemia among the HIV- infected children on HAART (Table 5).

Tables 6 shows the risk factors associated with Hypertriglyceridaemia amongst the HIV-infected children on HAART.

The children who were older than 5 years of age $(\mathrm{P}=0.02$; $\mathrm{OR}=2.78,95 \%$ CI: 0.76-10.23), duration of diagnosis of HIV infection greater than 1 year $(\mathrm{P}=0.02 ; \mathrm{OR}=2.23,95 \% \mathrm{CI}$ : 0.14 38.99) and duration on HAART regimen greater than 1 year $(\mathrm{P}=0.04)$ were found to be the factors significantly associated with hypertriglyceridaemia (Table 7). 


\section{Discussion}

Total cholesterol, LDL-cholesterol and triglycerides levels were found to be significantly higher among the studied children on HAART compared to HAART naïve children. However, the levels of HDL-cholesterol did not differ between the two groups. The elevations in serum lipids in HIV infection could be due to the replication of HIV in human T-cells. ${ }^{11}$ These elevations are further worsened by the use of HAART. ${ }^{12,13}$ A similar pattern of dyslipidaemia was reported in a group of HIV-infected adults in a Nigerian population by Awah et al in Asaba. ${ }^{14}$

The high prevalence of dyslipidaemia noted in this study can be attributed to the combination therapy of the HAART regimen, particularly the PI based antiretroviral drugs (lopinavir/ritonavirbased combinations) which are known to have lipid sparing effects. Also, the high prevalence of dyslipidaemia may be attributed to the long duration of treatment with HAART as this study showed the mean duration of treatment of about five years.

This study also showed that duration of diagnosis greater than 1 year was significantly associated with dyslipidaemia. Previous studies have shown that unfavourable lipid concentrations could begin to manifest within three to twelve months of commencement of PI-based therapy and the manifestation could be faster in those with ritonavir-based combinations. ${ }^{15}$ The studies conducted by

Table 1. Baseline characteristics of study subjects.

\begin{tabular}{|c|c|c|}
\hline Baseline characteristics & HAART $(n=80)$ & HAART NAIVE $(n=80)$ \\
\hline Mean age in years (SD) & $9.08 \pm 3.8$ & $9.00 \pm 3.67$ \\
\hline $\begin{array}{l}\text { Gender } \\
\text { Male } \\
\text { Female }\end{array}$ & $\begin{array}{l}47(58.7 \%) \\
33(41.3 \%)\end{array}$ & $\begin{array}{l}47(58.7 \%) \\
33(41.3 \%)\end{array}$ \\
\hline $\begin{array}{l}\text { Socio-economic class } \\
\text { I } \\
\text { II } \\
\text { III } \\
\text { IV } \\
\text { V }\end{array}$ & $\begin{array}{l}12(15.0 \%) \\
13(16.2 \%) \\
22(27.5 \%) \\
26(32.5 \%) \\
7(8.8 \%)\end{array}$ & $\begin{array}{c}2(2.5 \%) \\
3(3.8 \%) \\
23(28.7 \%) \\
40(50.0 \%) \\
12(15.0 \%)\end{array}$ \\
\hline $\begin{array}{l}\text { Medical history } \\
\text { Age at diagnosis [Median (IQR)] } \\
\text { Duration of diagnosis[Mean } \pm \text { SD]mo) } \\
\text { Age at commencement of ART[Mean } \pm \text { SD] }(\text { mo }) \\
\text { Duration on ART[Mean } \pm \text { SD] (mo) }\end{array}$ & $\begin{array}{c}30(48) \\
65.4(39.2) \\
49.8(44.03) \\
59.61(40.7)\end{array}$ & $\begin{array}{c}72(58) \\
37.8(31.7) \\
\text { NA } \\
\text { NA }\end{array}$ \\
\hline $\begin{array}{l}\text { HAART regimen } \\
\text { First line } \\
\text { Second line } \\
\text { Duration on current ART }(\mathrm{mo}) \\
\end{array}$ & $\begin{array}{l}46(57.5 \%) \\
34(42.5 \%) \\
30.8(17.8)\end{array}$ & $\begin{array}{l}\text { NA } \\
\text { NA } \\
\text { NA }\end{array}$ \\
\hline
\end{tabular}

mo -months $\mathrm{NA}=$ not applicable.

Table 2. Serum lipid profile (Mean \pm SD) of study subjects by group.

\begin{tabular}{lcccc} 
Lipid profile $(\mathrm{mmol} / \mathrm{L})$ & HAART NAIVE & T test & \\
Total Cholesterol & $5.34 \pm 1.30$ & $4.16 \pm 0.9$ & 6.58 & 0.001 \\
LDL-Cholesterol & $3.52 \pm 1.17$ & $2.51 \pm 0.88$ & 6.17 & .001 \\
\hline HDL-Cholesterol & $0.92 \pm 0.34$ & $0.86 \pm 0.23$ & 1.31 & 0.193 \\
Triglycerides & $1.88 \pm 0.58$ & $1.67 \pm 0.53$ & 2.39 & 0.018 \\
\hline
\end{tabular}

Table 3. Prevalence of Dyslipidaemia among the study subjects.

\begin{tabular}{|c|c|c|c|}
\hline Variable & HAART n (\%) & HAART NAIVE n (\%) & P value \\
\hline $\begin{array}{l}\text { Total Cholesterol } \\
\text { High } \\
\text { Normal }\end{array}$ & $\begin{array}{l}38(47.5) \\
42(52.5)\end{array}$ & $\begin{array}{c}9(11.3) \\
71(88.7)\end{array}$ & 0.001 \\
\hline $\begin{array}{l}\text { HDL Cholesterol } \\
\text { Low } \\
\text { Normal }\end{array}$ & $\begin{array}{l}43(53.8) \\
37(46.2)\end{array}$ & $\begin{array}{l}42(52.5) \\
38(47.5)\end{array}$ & 0.980 \\
\hline $\begin{array}{l}\text { LDL Cholesterol } \\
\text { High } \\
\text { Normal }\end{array}$ & $\begin{array}{l}33(41.3) \\
47(58.7)\end{array}$ & $\begin{array}{l}14(17.5) \\
66(82.5)\end{array}$ & 0.001 \\
\hline $\begin{array}{l}\text { Triglyceride } \\
\text { High } \\
\text { Normal }\end{array}$ & $\begin{array}{l}50(62.5) \\
30(37.5)\end{array}$ & $\begin{array}{l}38(47.5) \\
42(52.5)\end{array}$ & 0.014 \\
\hline
\end{tabular}


Table 4. Risk factors for hypercholesterolaemia in children on HAART.

\begin{tabular}{|c|c|c|c|c|c|}
\hline Variable & High TC n(\%) & Normal TC n(\%) & $\begin{array}{l}\text { TOTAL } \\
\mathrm{n}=80\end{array}$ & $\begin{array}{l}\text { Test statistic } \\
\qquad \chi^{2}\end{array}$ & P value \\
\hline $\begin{array}{l}\text { Age } \\
\quad \geq \text { yyears } \\
\quad<5 \text { years }\end{array}$ & $\begin{array}{c}29(43.9) \\
9(64.3)\end{array}$ & $\begin{array}{c}37(56.1) \\
5(35.7)\end{array}$ & $\begin{array}{l}66 \\
14\end{array}$ & 1.92 & 0.17 \\
\hline $\begin{array}{l}\text { Gender } \\
\text { Male } \\
\text { Female } \\
\end{array}$ & $\begin{array}{l}20(42.6) \\
18(54.6)\end{array}$ & $\begin{array}{l}27(57.4) \\
12(45.4)\end{array}$ & $\begin{array}{l}47 \\
33 \\
\end{array}$ & 1.12 & 0.29 \\
\hline 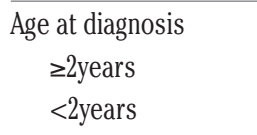 & $\begin{array}{l}22(42.3) \\
16(57.1)\end{array}$ & $\begin{array}{l}30(57.7) \\
12(42.9)\end{array}$ & $\begin{array}{l}52 \\
28\end{array}$ & 1.61 & 0.21 \\
\hline $\begin{array}{l}\text { Duration of diagnosis } \\
\quad \geq \text { lyear } \\
\quad<\text { lyear }\end{array}$ & $\begin{array}{c}38(50.0) \\
0\end{array}$ & $\begin{array}{l}38(50.0) \\
4(100.0)\end{array}$ & $\begin{array}{c}76 \\
4\end{array}$ & & 0.12 \\
\hline $\begin{array}{l}\text { Age at HAART } \\
\quad \geq 2 \text { years } \\
<2 \text { years }\end{array}$ & $\begin{array}{l}21(39.6) \\
17(63.0)\end{array}$ & $\begin{array}{l}32(60.4) \\
10(37.0)\end{array}$ & $\begin{array}{l}53 \\
27\end{array}$ & 3.91 & 0.048 \\
\hline $\begin{array}{l}\text { Duration on HAART } \\
\geq \text { lyear } \\
<\text { lyear }\end{array}$ & $\begin{array}{c}34(49.3) \\
4(36.4)\end{array}$ & $\begin{array}{c}35(50.7) \\
7(63.4)\end{array}$ & $\begin{array}{l}69 \\
11 \\
\end{array}$ & 0.63 & 0.43 \\
\hline $\begin{array}{l}\text { HAARTRegimen } \\
\text { PI based } \\
\text { Non PI based } \\
\end{array}$ & $\begin{array}{c}24(70.6) \\
14(30.4) \\
\end{array}$ & $\begin{array}{l}10(29.4) \\
32(69.6)\end{array}$ & $\begin{array}{l}34 \\
46 \\
\end{array}$ & 12.64 & 0.001 \\
\hline
\end{tabular}

Table 5. Multivariate analyses for risk factors for hypercholesterolaemia in children on HAART.

\begin{tabular}{|c|c|c|}
\hline Risk factor for Hypercholesterolaemia & Adjusted Odds Ratio (95\% CI) & p value \\
\hline $\begin{array}{l}\text { Age at HAART (years) } \\
\text { Less than } 2 \text { (referent) } \\
\text { Greater than or equal to } 2\end{array}$ & $0.38(0.13-1.08)$ & 0.07 \\
\hline $\begin{array}{l}\text { HAART Regimen } \\
\text { PI based (referent) } \\
\text { Non-PI based }\end{array}$ & $0.18(0.07-0.49)$ & 0.001 \\
\hline
\end{tabular}

Table 6. Risk Factors for Hypertriglyceridaemia in children on HAART.

\begin{tabular}{|c|c|c|c|c|c|}
\hline Variable & High TC n(\%) & Normal TC n(\%) & $\begin{array}{l}\text { TOTAL } \\
\mathrm{n}=80\end{array}$ & $\begin{array}{c}\text { Test statistic } \\
\chi^{2}\end{array}$ & P value \\
\hline $\begin{array}{l}\text { Age Group } \\
\geq 5 \text { years } \\
<\text { 5years }\end{array}$ & $\begin{array}{l}45(68.2) \\
5(35.2)\end{array}$ & $\begin{array}{c}21(31.8) \\
9(64.3)\end{array}$ & $\begin{array}{l}66 \\
14\end{array}$ & 5.20 & 0.02 \\
\hline $\begin{array}{l}\text { Gender } \\
\text { Male } \\
\text { Female } \\
\end{array}$ & $\begin{array}{l}30(63.8) \\
20(60.6)\end{array}$ & $\begin{array}{l}17(36.2) \\
13(39.4)\end{array}$ & $\begin{array}{l}47 \\
33\end{array}$ & 0.09 & 0.77 \\
\hline $\begin{array}{l}\text { Age at diagnosis } \\
\quad \geq 2 \text { years } \\
<2 \text { years }\end{array}$ & $\begin{array}{l}33(63.5) \\
17(60.7)\end{array}$ & $\begin{array}{l}19(36.5) \\
11(39.30\end{array}$ & $\begin{array}{l}52 \\
28\end{array}$ & 0.06 & 0.81 \\
\hline $\begin{array}{l}\text { Duration of diagnosis } \\
\quad \geq \text { lyear } \\
\quad<\text { lyear }\end{array}$ & $\begin{array}{c}50(65.8) \\
0\end{array}$ & $\begin{array}{l}26(34.2) \\
4(100.0)\end{array}$ & $\begin{array}{c}76 \\
4 \\
\end{array}$ & & 0.02 \\
\hline $\begin{array}{l}\text { Age at HAART } \\
\quad \geq 2 \text { years } \\
<2 \text { years }\end{array}$ & $\begin{array}{l}33(62.3) \\
17(63.0)\end{array}$ & $\begin{array}{l}20(37.7) \\
10(37.0)\end{array}$ & $\begin{array}{l}53 \\
27\end{array}$ & 0.004 & 0.95 \\
\hline $\begin{array}{l}\text { Duration on HAART } \\
\quad \geq \text { lyear } \\
\quad<\text { lyear } \\
\end{array}$ & $\begin{array}{c}49(65.3) \\
1(20.0)\end{array}$ & $\begin{array}{c}26(34.7) \\
4(80.0)\end{array}$ & $\begin{array}{c}75 \\
5 \\
\end{array}$ & 4.11 & 0.04 \\
\hline $\begin{array}{l}\text { HAARTRegimen } \\
\text { PI based } \\
\text { Non PI based } \\
\end{array}$ & $\begin{array}{l}19(55.9) \\
31(67.4)\end{array}$ & $\begin{array}{l}15(44.1) \\
15(32.6)\end{array}$ & $\begin{array}{l}34 \\
46 \\
\end{array}$ & 1.11 & 0.29 \\
\hline
\end{tabular}


Table 7. Multivariate analyses of risk factors for hypertriglyceridaemia in children on HAART.

\begin{tabular}{|c|c|c|}
\hline Risk factor for Hypercholesterolaemia & Adjusted Odds Ratio (95\%Cl) & p value \\
\hline $\begin{array}{l}\text { Age Group (years) } \\
\text { Less than } 5 \\
\text { Greater than or equal to } 5 \text { (referent) }\end{array}$ & $2.78(0.76-10.23)$ & 0.12 \\
\hline $\begin{array}{l}\text { Duration on HAART (year) } \\
\text { Less than } 1 \\
\text { Greater than } 1\end{array}$ & $2.32(0.14-38.99)$ & 0.56 \\
\hline
\end{tabular}

Vigano et $a l^{16}$ and Farley et $a l^{17}$ also reported similar findings of higher prevalence of lipid disorders among HIV-infected children and adolescents on HAART.

The prevalence of the various forms of dyslipidaemia observed in this study are similar to the findings of Amaya et al ${ }^{18}$ in a study conducted on a group of $40 \mathrm{HIV}$-infected children in the United States of America on PI- and non PI-based HAART regimens. They reported a prevalence of hypercholesterolaemia and hypertriglyceridaemia of $68 \%$ and $28 \%$ respectively. Also in Uganda, Piloya et al. ${ }^{19}$ reported a prevalence of hypercholesterolaemia of $16.8 \%$ and hypertriglyceridaemia of $83.2 \%$. The differences in prevalence rates could be due to varying effects of the antiretroviral drugs, particularly the PIs. ${ }^{20}$ Various types of diets could also be associated with the pathogenesis of HAART-related dyslipidaemia, as the children studied were from different parts of the world. ${ }^{20}$

Lower serum lipid levels were found among the HIV-infected HAART naïve children compared to the HAART treated group in this study. Similarly, Chantry et al.,21 in the USA also reported lower serum lipid levels in HAART naïve children.

Hypertriglyceridaemia and low HDL-cholesterol were the most common form of lipid abnormalities observed among the studied HAART naive group. Similar findings were also reported by Kanjanavanit et al. ${ }^{22}$ in a group of $274 \mathrm{HIV}$-infected HAART naïve Thai and Cambodian children aged 1 to 12 years.

In the HAART treated group, total cholesterol was found to be significantly elevated in the children on PI-based HAART regimen (which also contains NRTIs) compared to the children on the nonPI-based HAART regimen (which contains both NRTIs and NNRTI). However, there was no significant difference in the elevated triglyceride levels among the two groups. This observation corroborates the findings of Brewinski et al., ${ }^{23}$ in a cohort of HIVinfected Latin American children on PI-based HAART regime which showed that the children were at increased risk of hypercholesterolaemia and hypertriglyceridaemia compared with the children that were on NNRTI-containing HAART regimen.

Factors associated with hypercholesterolaemia and hypertriglyceridaemia among the HIV- infected children on HAART noted in this study were age at commencement of HAART greater than 2 years, PI-based HAART regimen, age group greater than 5 years, duration of HIV diagnosis greater than 1 year and duration of treatment with HAART of more than I year. However, after controlling for confounders on multivariate analysis, PI-based HAART regimen was the only factor found to be independently associated with hypercholesterolaemia in HAART treated group. Farley et al., ${ }^{17}$ in a large group of 1,812 HIV-infected children in the USA, found that the use of PI-based HAART regimen, ages from 4 to $<6$ years, HIV-1 RNA $<400$ copies $/ \mathrm{mL}$, good adherence and the use of NNRTI were independently associated with hypercholesterolaemia.
No significant relationship was observed between gender, hypercholesterolaemia and hypertriglyceridaemia in this study. This was similar to the findings of Brewinski et al., ${ }^{23}$ in a group of HIV infected Latin American children. In this study, there was also no significant association between socio-economic class, hypercholesterolaemia and hypertriglyceridaemia. This could be due to exposure of the children to the same staple food within the community. Though a greater proportion of the children were in social class 4 and 5, almost all the children recruited for the study lived within Kano metropolis which is an urban settlement.

\section{Conclusions}

The aim of the study was to compare the prevalence and risk factors for dyslipidaemia among HIV-infected children on HAART and HIV-infected HAART naive children aged 2-15 years attending the Aminu Kano Teaching Hospital, Kano.

It could be concluded from the observations made in this study that the prevalence of dyslipidaemia was higher in the HIV infected HAART treated children than the HIV infected HAART naive children.Also, the prevalence of hypercholesterolaemia was higher in patients on PI-based HAART regimen than those on non -PIbased HAART regimen. The risk factor strongly associated with dyslipidaemia was PI-based HAART regimen. Other risk factors for dyslipidaemia identified in the study were age group greater than 5 years, commencement of HAART in children greater than 2 years of age, duration of HIV diagnosis more than 1 year and duration of treatment on HAART for more than 1 year.

\section{Recommendations}

All HIV positive children should have pre-HAART baseline lipid profiles measured followed by periodic assessments. The treatment regimen with the lowest risk for dyslipidaemia should be offered to patients as the second line treatment option. Patients identified with dyslipidaemia should be commenced immediately on the various treatment options available for children and adolescents.

\section{References}

1. Vigano N, Cerini C, Pattarino G, et al. Metabolic complications associated with antiretroviral therapy in HIV-infected and HIV-exposed uninfected paediatric patients. Expert Opin Drug Saf 2010;9:431-45.

2. Carr A, Cooper DA. Adverse effects of antiretroviral therapy. Lancet 2000;356:1423-30.

3. Herman JS, Easterbrook PJ. The metabolic toxicities of antiretroviral therapy. Int J Std Aids 2001;9:555-62. 
4. Lainka E, Oezbek S, Falck M, et al. Marked dyslipidaemia in human immunodeficiency virus infected children on protease inhibitor-containing antiretroviral therapy. Paediatr 2002;110:e56.

5. Barlow-Mosha L, Eckard AR, McComsey GA, et al. Metabolic complications and treatment of perinatally HIV-infected children and adolescents. J Int AIDS Soc 2013;16:18600.

6. McComsey GA, Leonard E. Metabolic complications of HIV therapy in children. AIDS 2004;18:13.

7. Oyedeji GA. The present day epidemiology of severe protein energy malnutrition in Nigeria. Clin Paediatr 1984;23:623-8.

8. Allan CC, Poon LS, Chen CSG. Enzymatic determination of total serum cholesterol. Clin Chem 1974;20: 470-7.

9. McGowan MW, Artiss JD, Standberg DR. A peroxidase-coupled method for colorimetric determination of serum triglycerides. Clin Chem 1983;29:583-542.

10. Friedwald WT, Levy RI, Fredrickson DS. Estimation of the concentration of low-density lipoprotein cholesterol in plasma without the use of the preparative ultracentrifuge. Clin Chem 1972; 18:499-503.

11. Rasheed S, Yan JS, Lau A, et al. HIV replication enhances production of free fatty acids, low density lipoprotein and many key proteins involved in lipid metabolism a proteonomic study. PloS ONE 2008;3:e3003.

12. Hellerstein $\mathrm{MK}$, Grunfeld $\mathrm{C}, \mathrm{Wu} \mathrm{K}$, et al. Increased de-novo hepatic lipogenesis in human immunodeficiency virus infection. JCEM 1993;76:559-65.

13. Leonard EG, McComsey GA. Metabolic complications of antiretroviral therapy in children. Paediatr Infect Dis J 2003;22:7784.

14. Awah FM, Agughasi O. Effect of highly active antiretroviral therapy on lipid profile in a human immunodeficiency virus infected population. Afr J Biochem Res 2011;5:282-6.
15. Calza L, Manfredi R, Chiodo F. Hyperlipidaemia in patients with HIV-1 infection receiving highly active antiretroviral therapy. Int J Antimicrobial Agents 2003;22:89-9.

16. Vigano A, Thorne C, Brambilla P, et al. European Paediatric Lipodystrophy Group. Antiretroviral therapy, fat redistribution and hyperlipidaemia in HIV-infected children in Europe. AIDS 2004; 18:1443-51

17. Farley J, Gona P, Crain M, et al. Prevalence of hypercholesterolaemia and associated risk factors among perinatally HIVinfected children (4-19years) in PACTG 219. 10th conference of retroviruses and opportunistic infections. Boston MA, USA: 2003.

18. Amaya RA, Kozinetz CA, McMeans A. Lipodystrophy syndrome in Human Immunodeficiency Virus-infected children. Paediatr Infect Dis J 2002;21:405-10.

19. Piloya T, Bakeera-Kitaka S, Kamya MR. Lipodystrophy among HIV-infected children and adolescents on highly active antiretroviral therapy in Uganda; a cross sectional study. J Int AIDS Soc 2012;15:17427.

20. Jisun $\mathrm{OH}$, Hegele RA. HIV-associated dyslipidaemia: pathogenesis and treatment. LANINF 2007;12:787-96.

21. Chantry CJ, Hughes MD, Alvero C, et al. Lipid and glucose alterations in HIV- infected children beginning or changing antiretroviral therapy. Paediatr 2008;122:129-38.

22. Kanjanavanit S, Puthanakit T, Vibol U, et al. High prevalence of lipid abnormalities among antiretroviral naive HIV- infected Asian children with mild to moderate immunosuppression. Antivir Ther 2011;16:1351-5.

23. Brewinski M, Megazzini K, Hance LF, et al. Dyslipidaemia in a cohort of HIV- infected Latin American children receiving highly active antiretroviral therapy. J Trop Paediatr 2011;57:324-32. 